\title{
Angiogenesis: A cellular response to traumatic injury
}

Anthony R. Pecoraro ${ }^{1}$, Brian D. Hosfield ${ }^{1}$, Hongge $\mathrm{Li}^{1}$, W. Christopher Shelley ${ }^{1}$ and Troy A. Markel ${ }^{1 *}$

${ }^{1}$ Department of Surgery, Indiana University School of Medicine, Indianapolis, IN, USA

Corresponding Author Address:

Troy Markel, MD, FACS, FAAP

Assistant Professor of Surgery

Indiana University School of Medicine

Riley Children's Hospital

705 Riley Hospital Dr.

RI 2500

Indianapolis, IN 46202

Email: tmarkel@iupui.edu

Phone: $317-437-2506$

\section{Abstract}

The development of new vasculature plays a significant role in a number of chronic disease states, including neoplasm growth, peripheral arterial disease, and coronary artery disease, among many others. Traumatic injury and hemorrhage, however, is an immediate, often dramatic pathophysiologic insult which can also necessitate neovascularization to promote healing. Traditional understanding of angiogenesis involved resident endothelial cells branching outward

This is the author's manuscript of the article published in final edited form as:

Pecoraro, A. R., Hosfield, B. D., Li, H., Shelley, W. C., \& Markel, T. A. (2020). Angiogenesis: A Cellular Response to Traumatic Injury. Shock, Publish Ahead of Print. https://doi.org/10.1097/SHK.0000000000001643 
from localized niches in the periphery. Additionally, there are a small number of circulating endothelial progenitor cells which participate directly in the process of neovessel formation. The bone marrow stores a relatively small number of so-called pro-angiogenic hematopoietic progenitor cells (PACs) - that is, progenitor cells of a hematopoietic potential that differentiate into key structural cells and stimulate or otherwise support local cell growth/differentiation at the site of angiogenesis. Following injury, a number of cytokines and intercellular processes are activated or modulated to promote development of new vasculature. These processes initiate and maintain a robust response to vascular insult, allowing new vessels to canalize and anastomose and provide timely oxygen delivering to healing tissue. Ultimately as we better understand the key players in the process of angiogenesis we can look to develop novel techniques to promote healing following injury.

Keywords: hematopoietic stem cells, vascular endothelial growth factor, neovascularization, extracellular matrix, CXCL12, hypoxia-inducible factor, matrix metalloproteinase

\section{Introduction}

The development of new vasculature plays a significant role in traumatic injury and hemorrhage particularly during the acute phase of organ repair. Long-held theories concerning the development of new vasculature primarily focus on local endothelial and circulating endothelial progenitor cells. A cell of hematopoietic lineage stored in bone marrow, termed the proangiogenic hematopoietic progenitor cell (PAC), has also been identified that plays an important role in paracrine signaling and structural development of new vessels. $(1,2)$ This otherwise quiescent cell type interacts with a multitude of key signaling molecules both for storage and release as needed and is a key contributor to the development of needed vasculature in the post-natal human. The cascade of cytokine release and PAC mobilization is complex, 
multifaceted, and tightly regulated by a number of important feedback loops. This cascade is particularly important in an abrupt deviation from homeostasis, as in the case of traumatic injury, particularly considering the immediately increased need for oxygen and nutrients by injured tissues.(3) Study of these HSCs may ultimately provide a better understanding of the varying healing potential of injured and severely ill patients. The purpose of this review is to: 1) summarize the process of angiogenesis at the level of neovessel formation, 2) identify key signaling molecules involved in the angiogenic process, and 3) identify how proangiogenic stem cells can improve outcomes following traumatic injury.

\section{Angiogenesis}

\section{Embryology}

The human vascular system begins to develop around the seventeenth day of gestation. Clusters of primarily early erythrocytes are surrounded by vascular endothelial growth factor-positive endothelial progenitor cells (EPCs) in the yolk sac. These EPCs will develop into endothelial cells, and ultimately coalesce to form tubes in a process termed vasculogenesis. As the responsibility for blood cell formation is transitioned from the yolk sac to the embryonic organs, these same organs become colonized with mature hematopoietic stem cells. Until the time of birth, the primary responsibility for the development and differentiation of hematopoietic cells lies with the liver before ultimately colonizing the bone marrow(4). As the embryo develops, the splanchnic mesoderm differentiates into a primitive vascular system. Further budding of the vascular branches - termed angiogenesis - subsequently occurs (5). Vasculogenesis in the developing embryo is subject to a number of regulatory pathways and molecules, including mechanical strain(6), fibroblast growth factors and associated tyrosine kinase receptors(7), as well as specific cell adhesion molecules such as VE-cadherin and Ang-2(8). 


\section{Conditions Precipitating Angiogenesis and the Vascular Extracellular Matrix}

Angiogenesis is the result of a complex cascade of signaling molecules and cell-cell interactions. In a physiologic state, normal human endothelial cells are closely connected via vascular endothelial cadherin (VE-cadherin) at adherens junctions, and occludin and JAM-1 at tight junctions. These junctions form a transendothelial barrier against the free passage of ions, solutes, and lipids from the apical to basolateral cell surfaces.(9) They also provide the basis for imperative cell-cell functions which allow the endothelial cell, under the appropriate conditions, to quickly sprout new cells in a direction of need. $(10,11)$ Transgenic mice with knockout of genes encoding involved proteins - for example $\beta$-catenin(12)-demonstrated impaired endothelial maturation, vessel fragility, and disorganization that was frequently incompatible with life.

The pathophysiologic conditions under which angiogenesis occurs vary - i.e. wound healing, cancer, hypoxia, etc. - but the cellular mechanisms underlying the eventual sprouting of new vessel structures have commonalities. Microvascular permeability to plasma proteins appears to be a relatively early event in the formation of new vessels. As have been described, both interendothelial and trans-endothelial passages are opened as a downstream effect of vascular endothelial growth factor (VEGF) signaling. This allows the translocation of proteins necessary for the scaffolding of the fibrin-rich extracellular matrix.(13) As endothelial cells begin to migrate into the surrounding extracellular matrix (ECM), a number of key molecules exert strong effects on proliferation and tubulogenesis. Fibronectin, an ECM protein, is upregulated from its otherwise barely detectable concentration in angiogenetic pathologies.(14) Endothelial cells involved in neovascularization have demonstrated unfolding of fibronectin to create a 
pericellular network of fibrils, which supports organization and migration of tubular cells in a type I collagen-dominant extracellular matrix. $(15,16)$

Another group of molecules key to maintaining perivascular homeostasis are laminins. Laminins are a group of polymers containing three polypeptide chains $-\alpha, \beta$, and $\gamma$, giving rise to 16 different isoforms, each with tissue-specific functions.(17) The $\alpha 4$ subunit, in particular, plays a critical role in interacting with integrins, namely $\alpha \mathrm{v} \beta 3$ and $\alpha 3 \beta 1$, all of which serve to interact with endothelial cells and promote angiogenesis.(18) These molecules, present in the vascular basement membrane, have shown important roles in maintenance of vessel homeostasis as well, particularly in settings of homeostasis and fluid shear stress.(19) Laminin, type IV collagen, fibrin, and other factors make up the perivascular ECM which provides the initial scaffolding through which new vessels may form.

The Process of Angiogenesis

Angiogenic endothelial cells are generally characterized as either leading "tip" cells or trailing "stalk" cells. Tip cells, selected by Delta-like 4-Notch1 signaling and induced to angiogenic activity by VEGF-A, lead the way into the vascular basement membrane (vBM).(20) Notch signaling has been shown to not only identify tip cells, but keep stalk cells in position and prevent development of tip-like behavior. Maintaining cells in a stalk position is crucial for lumen formation and connection to existing vasculature as the new vessel sprouts and migrates.(21)

In order to sprout new vasculature, angiogenic cells must first penetrate and degrade the vBM. Recent evidence using an in vivo model of transgenic and knockout mice demonstrated that endothelial cells, after sensing angiogenic signals, develop podosome rosettes, which are capable of invading and degrading the vBM.(22) This appears to be the key initial step in development of 
new tubular vascular branches. Recent evidence shows that podosome formation coincides with loss of perivascular type IV collagen in a VEGF/Notch-dependent pathway.(23)

Following entry into the basement membrane, proangiogenic endothelial cells are tasked with proliferation and new tubule formation, followed by maturation. Relatively little is known about the migration of endothelial cells in a three-dimensional matrix. Endothelial cells have been shown to migrate in functionally distinct patterns depending on the concentration of certain structural substrates in the surrounding migration matrix. In dense Matrigel, endothelial cells demonstrated an elongated pattern depositing dense ECM with migration, whereas in fibrillar collagen I-dominant matrix (notably lacking laminin), the cells take on a rounded shape of amoeboid-type migration with significant intracellular blebbing noted.(24) As cells migrate, endothelial cell interactions with ECM components promote tube formation. Laminin-511, particularly the $\alpha 5$ short arm, has demonstrated activity for both endothelial cell attachment and tube formation in vitro.(25) Hemodynamic stress within existing vessels, coupled with lumen formation in angiogenic sprouts prior to connection, result in a tightly regulated expansion of existing vasculature into new territory. $(26,27)$

As new vessels sprout, cell-cell signaling continues to play a crucial role, not only for maintenance of homeostasis but tight control of cells moving around one another and developing appropriate polarity. Appropriate apico-basal polarity is essential for tubule formation by migrating endothelial cells, a key part of a multistep process to allow branching endothelium to carry blood products.(28) During sprouting, VE-cadherin integrity at cell-cell junctions once more plays a crucial role. VE-cadherin is phosphorylated and translocated from the cell membrane in settings with high VEGF and/or Notch concentration.(29) This variability allows 
cells to jostle position in areas of need while maintaining the structural integrity of the existing vascular structure.

\section{Angiogenesis in the Healing Process}

When tissue is injured, the initial angiogenetic response results in a surge of capillary growth that is orders of magnitude more dense than uninjured tissue. This occurs by the process described above and is mediated in accordance with the surge in cell signaling molecules that will be described in later sections. Capillaries sprout quickly and are subsequently pruned to create mature vasculature for the delivery of adequate oxygen and nutrients to the healing bed. This is correlated with a decline in circulating proangiogenic factors and allows secondary stages of healing to begin. Indeed, the argument can be made that the angiogenic response to injury results in wounds that heal with marked fibrosis. The resulting massive surge in capillary density may promote local inflammation to an unnecessarily robust degree.(30)

Clinically, a great deal of attention has been paid to understanding and optimizing wound healing and angiogenesis. While the key steps remain consistent - that is, migration into and through extracellular matrix, tube formation, maturation, and anastomosis - conditions that cause a global alteration of physiology such as polytrauma, induce a cascade of cell signals which can induce or impair any or all of those steps of angiogenesis. We will subsequently discuss those signals, as well as their known or presumed role in the development of new vasculature.

\section{Cells Involved in Angiogenesis}

Endothelial outgrowth involves two general types of precursor cells which fall under the umbrella of endothelial progenitor cell (EPC). The first, termed the late-outgrowth endothelial colony forming cell, is a relatively differentiated, committed endothelial cell that is used to form new or repair damaged endothelium. These cells, in response to angiogenic signals, align in tip 
or stalk roles as described above to facilitate the outward branching of existing vasculature. The second cell type, proangiogenic hematopoietic progenitor cells (PACs), serve to stimulate and enhance angiogenesis via paracrine mechanisms. These PACs are frequently bone marrowderived cells released into circulation via a variety of signaling cascades.(31) Flow cytometry has been utilized to elucidate the extracellular markers specific to PACs, and while the particular cell surface signature of these molecules has been known for some time, their function is continually being described. The most frequent cell surface protein signature used to identify circulating proangiogenic hematopoietic-lineage cells is CD $34^{+} \mathrm{CD} 133^{+}$VEGFR2 ${ }^{+}$. $(32,33)$ Peichev, et al., demonstrated a distinct cell lineage of $\mathrm{CD} 34^{+} \mathrm{CD} 133^{+}$VEGFR $2^{+}$cells which formed a neo-intima on left ventricular assist devices, thereby uncovering a crucial role in angiogenesis.(34) Data has demonstrated that $\mathrm{CD} 33^{+} \mathrm{CD} 45^{+}$ cells are of hematopoietic-restricted lineage, and do not differentiate into endothelial cells proper to form new blood vessels.(35) Nevertheless, this signature of cell surface proteins does appear to identify a group of phenotypically distinct hematopoietic cells which participate in postnatal angiogenesis.

Hematopoietic progenitor cells stored in bone marrow migrate into the periphery in the setting of traumatic hemorrhage. They have been shown to be a potential marker for mortality following a major traumatic event.(3) Proper identification of these cells - as well as the associated circulating stimuli for release - may not only yield prognostic information, but may also allow for cellular therapies to be developed for rapid revascularization following organ injury.(36)

\section{Maintenance of Quiescent PACs}

At steady state, there exists a delicate cellular signaling interplay that serves to maintain a supply of pro-angiogenic hematopoietic progenitors. The first of these cell surface molecules is C-X-C 
chemokine motif ligand 12 (CXCL12). CXCL12 is a chemokine mutually exclusive to the seven transmembrane G-protein coupled receptor CXCR4, which is expressed on bone marrow-derived hematopoietic stem and progenitor cells. Bone marrow stromal cells express CXCL12 at steady state, which promotes maintenance of CD34+/CD38-/ ${ }^{\text {low }} \mathrm{HSCs}$ in mice. $(37,38)$ This has been shown in mice to promote maintenance of bone marrow HPCs and HSCs.(37) When the CXCL12-CXCR4 axis is compromised, both maintenance and migration of HPCs are impaired. When the CXCL12-CXCR4 axis is impaired, PAC maintenance and migration are both impaired. AMD3100 is a specific inhibitor of CXCR4 that competes with CXCL12, multiple studies have demonstrated that administration of AMD3100 resulted in rapid mobilization of hematopoietic progenitor cells from bone marrow to peripheral circulation.(39) This includes early PACs with long-term repopulation potential. (40-42) Bach, et al., demonstrated that antagonism of CXCR4 with AMD3100 in pigs who sustained polytrauma resulted in a sharp increase in circulating CXCL12 levels, suggesting a regulatory feedback loop.(43) Indeed, a recent study has demonstrated the imperative role of the CXCR4-CXCL12 axis in HPC maintenance, as well as homing for repopulation of bone marrow after myeloablation.(44) With this understanding of the key player in HPC maintenance, we can look at contributors to migration, particularly in the setting of traumatic injury, that serve to mobilize this cohort of proangiogenic cells when required.

\section{Mobilization of HPCs from Bone Marrow Niche}

Perhaps more intricate than the cellular interplay required for HPC maintenance, a number of cytokines and chemokines function to mobilize these cells when called upon.(Figure 1) These cyto/chemokines frequently have multiple functions as it relates to the immediate healing 
process. Each will be discussed both generally and as it relates specifically to the mobilization of HPCs from the bone marrow. Traumatic injury itself is not an entirely unique physiologic phenomenon. Many of the cellular responses to injury parallel those of other well-studied processes, including shock and sepsis.

Following traumatic injury, plasma levels of circulating CXCL12 increase with even higher concentration adjacent to the site of injury in humans.(45)Elevation of CXCL12 after trauma is similarly observed in patients with severe sepsis/septic shock.(46) As stated above the CXCL12CXCR4 axis is crucial to interaction with bone marrow-derived HPCs. While it may serve to promote steady-state quiescence, it also serves as a key homing molecule when proangiogenic cellular precursors are needed in an extramedullary capacity - namely at the site of injury. Akin to interaction with HPCs, inhibition of the CXCL12-CXCR4 axis impaired migration of bone marrow-derived mesenchymal stem cells.(47) The ligand is able to cross the bone marrow endothelium and reach the endosteum, interacting with early PACs and hematopoietic stem cells (HSCs).(48) Jin, et al., demonstrated in a mouse model that platelet-originated CXCL12 enhances neovascularization by its interaction with CXCR4+ cells of hematopoietic lineage.(49) (Figure 2)

To fully understand the role of CXCL12, an attempt should be made to understand additional downstream factors that are affected when it is upregulated. One such factor is matrix metalloproteinase 9 (MMP-9). MMP-9 belongs to a family of zinc endopeptidases that function at a physiologic $\mathrm{pH}$ to degrade ECM. The proenzymes are cleaved via thiol-modifying reagents, heat, chaotropic agents, and various other proteases.(50) MMP-9 has been shown to result in elevated CXCL12 levels, and reciprocally CXCL12 increased MMP-9 concentration in bone marrow cells.(51) Increases in circulating MMP-9 concentration have been observed following 
traumatic insult.(52-54) This is quite similar to studies demonstrating the increase of MMP-9 in patients with sepsis.(55-57) MMP-9 release has been shown to be associated with endotoxemia and hematopoietic cell migration from bone marrow to peripheral organs.(58)The broad degradative function of MMP-9 results in a number of downstream effects. With regards to blood vessel development, the importance of MMP-9 begins with embryonic vasculogenesis. Theodore, et al., demonstrated that MMP-9 inhibition in zebrafish resulted in decreased tail vascularity and increased numbers of PACs within caudal hematopoietic tissue.(59) Postembryologically, endothelial cells create and release several matrix metalloproteases, including MMP-1, MMP-2, MMP-9, and MT1-MMP. The shedding of membrane vesicle-associated components containing MMP-2, MMP-9, and MT1-MMP comes about as a rapid response to angiogenetic signals.(60) The ECM-degrading property of MMPs acts locally to break down perivascular ECM and well as distantly to mobilize HSCs and proangiogenic HPCs. MMP-9 has been shown in mice to affect migration of PACs from the quiescent to the proliferative niche via release of soluble Kit-ligand (sKitL). This allows PACs to rapidly respond to BM suppressive insult and repopulate myeloid and lymphoid progenitor cell lineages after significant mobilization into the periphery.(61) By distilling this expansive degradative function, we can deduce that MMP-9 is not only key for angiogenesis at the level of local vascular injury, but also for disruption of HPCs in a quiescent state, thus promoting mobilization into the periphery. A third key molecule involved in both maintenance and mobilization of PACs is transforming growth factor-beta (TGF $\beta$ ). TGF $\beta$ is a pleiotropic polypeptide that has a role in processes from embryological development to wound healing. TGF $\beta$ also exerts powerful, variable effects on angiogenesis. Firstly, it plays an important role in the transformation of HSCs into endothelial cells.(62) The receptor with which local TGF $\beta$ is interacting appears to play an important role in 
determining the function of this molecule. Activation of ALK5 generally favors stabilization in new vasculature, while activation of ALK1 favors sprouting.(63) In the course of inhibiting angiogenesis, TGF $\beta$ has demonstrated a dose-dependent inhibition of SMAD2, Notch pathway, and VEGFR2.(64)

Besides direct effects on angiogenesis at the site of new vessel development, TGF $\beta$ also acts in the bone marrow to induce quiescence in hematopoietic stem and progenitor cells. Recent research has identified the interaction of TGF $\beta$ with activation of downstream plasminogen activator inhibitor (PAI)-1 as important in the maintenance of PACs residing within the bone marrow niche. With this axis inhibited, PACs demonstrated MT1-MMP-dependent motility patterns and egress from bone marrow.(65)

Following traumatic injury, circulating levels of TGF $\beta$ have been shown to be elevated, peaking on post-injury day 3.(66) This is thought to contribute to the transient immunosuppression that occurs following trauma, but may also have an effect on responsive angiogenesis with the ALK5-dependent inhibition of PACs and angiogenic endothelial cells. Additionally, TGF $\beta$ exposure has been shown to induce formation of endothelial podosome rosettes both in vivo and in vitro, which allow invasion into perivascular basement membrane. $(67,68)$ The precise role of elevated TGF $\beta$ on the mobilization of PACs from bone marrow remains unclear, however the role of this cytokine at the site of neovascularization is well-described.

Like TGF $\beta$, vascular endothelial growth factor (VEGF) plays a role in both PAC mobilization and angiogenesis. Regarding the former, VEGF receptor 2-positive (VEGFR2+) endothelial cell forming unit concentration in peripheral blood increased in response to VEGF administration, suggesting the importance of VEGF in releasing proangiogenic progenitor cells from the bone marrow. This interaction appears to be MMP-9 dependent, as MMP-9-- did not demonstrate the 
same response to VEGF.(61)Similarly, depleted expression of VEGFR-2 via adeno-associated virus-mediated CRISPR-associated endonuclease has been demonstrated to inhibit angiogenesis in vitro.(69)VEGF levels following traumatic injury have been observed to be insignificantly altered; however, sVEGFR1 was positively correlated with injury severity score (ISS). Alternately, sVEGFR2 was negatively correlated with ISS. This finding is consistent with acute lung injury in sepsis, with multi-organ downregulation of VEGFR2 genes noted in experimental critical illness.(70)While not as overtly pro-angiogenic as VEGFR2, VEGFR1 is shown to be related to pathological angiogenesis (i.e., ischemia, tumorigenesis) as it is expressed on endothelial cells. $(71,72)$

Krüppel-like factor-10 (KLF-10) is a member of the zinc-finger family of proteins with diverse regulatory function, including that of osteoblasts, hepatocytes, and bone marrow-derived progenitor cells. KLF-10 targets the VEGFR-2 promotor in HSCs with pro-angiogenic behavior. Pro-angiogenic cells derived from the bone marrow demonstrated strong expression of transforming growth factor beta 1 (TGF- $\beta 1$ )-responsive KLF-10, according to Wara et al. Functionally, KLF-10 knockout resulted in impaired blood flow recovery in murine hind limb ischemia models.(73) Insofar as reconstitution of the endothelium, KLF-10 has been shown to be integral to the mobilization of pro-angiogenic precursor cells from the bone marrow, such that KLF- $10^{-/-}$mice demonstrate significantly impaired re-endothelization of injured carotid arteries after BM transplantation. To further investigate this phenomenon, the authors of this study evaluated the presence of other essential chemokines in BM HSC maintenance and migration. $\mathrm{KLF}-10^{-/-}$mice had impaired expression of CXCR4, which is imperative to maintenance and homing of PACs as previously discussed.(74) 
Other members of the Krüppel-like factor family, including KLF-2, KLF-4, KLF-5, KLF-6, and KLF-15 have demonstrated a role in angiogenesis through various other pathways. KLF-2, which is expressed on mature endothelial cells and upregulated in response to stress, has demonstrated ability to rejuvenate circulating proangiogenic cells, thereby promoting angiogenesis in times of need.(75) KLF-4 has been shown to activate VEGF signaling to stimulate angiogenesis.(76) KLF-15 acts via activation of the bone morphogenetic protein endothelial cell precursor-derived regulator (BMPER) pathway to stimulation new vessel growth.(77) KLF-5 appears to act by a variety of pathways, including VEGF, PAI-1, and PDGF, among a host of others.(78)

Taken in sum, these factors - CXCL12, MMP-9, TGF $\beta$, and VEGF - which frequently arise from the site of injury or directly adjacent circulating cells, work in concert to promote angiogenesis and mobilize distantly-stored key PACs to aid in this healing process.

\section{The Nervous System and PAC Maintenance and Migration}

In addition to egress of PACs from bone marrow stimulated by circulating cyto/chemokines, the autonomic nervous system has been shown to play a key role in maintaining and releasing PACs and stem cells from bone marrow niches. This is critical, as the sympathetic nervous system is acutely upregulated in response to traumatic injury and neuroimmune modulation is crucial to response and recovery.(79)In addition to chemokine-related steady state maintenance of PACs within the bone marrow niche, PACs have been shown to express neurotransmitter receptors in various quantities. Kalinkovich, et al., showed that more primitive CD34+CD38(-/low) cells express higher levels of neurotransmitter receptors, namely dopamine and $\beta$-adrenergic receptors. This is in concert with the high degree of sympathetic innervation of the bone marrow, which stores a large amount of dopamine.(80) When sympathetic tone is altered or dopamine conversion to norepinephrine is inhibited, egress of PACs from bone marrow when treated with 
granulocyte-colony stimulating factor (G-CSF) has been shown to be markedly impaired.(81) Macrophages also have the ability to modulate catecholamine release in the bone marrow, thus mobilizing PACs.(82) Méndez-Ferrer, et al., demonstrated that circadian norepinephrine release by the sympathetic nervous system controlled CXCL12 expression, which fluctuated in counter to concentration of PACs in peripheral blood.(83) The importance of $\beta$-adrenergic signaling in $\mathrm{CD} 34^{+}$cell maintenance and migration has been studied, as engraftment of progenitor cells, motility, and proliferation are all increased with greater neurotransmitter exposure.(84) Nerve growth factor (NGF) is a polypeptide first identified in the 1950s, noteworthy in this context for its ability to induce growth and differentiation in the developing embryo neural system. A review published in 1987 by Levi-Montalcini identifies this as a key function, and it has been further studied in nerves and non-nerve cells alike. $(85,86)$ With regards to angiogenesis, Cantarella, et al., demonstrated interaction with trkA and p57 proteins present on human umbilical vein endothelial cells. NGF was found to promote angiogenesis and endothelial cell proliferation in vivo.(87) Notably, NGF has been shown to be produced by microvascular endothelial cells in the human dermis, with potential implications for healing following traumatic injury.(88) Additionally, NGF has been shown to stimulate aorta endothelial cell migration via PI3K-dependent and ERK-dependent pathways, migrating according to an NGF gradient.(89) NGF and VEGF have been shown to have similar effects on the cardiovascular and nervous systems, respectively, and research is ongoing into the synergy between these two molecules.(90)

\section{Altered Systemic Physiology Resulting in PAC Mobilization}

In addition to the cellular response to and release of the cytokines and chemokines in the previous section, local and systemic physiologic changes following injury and shock result in 
mobilization of distant PACs. The first of these is hypoxia. Hypoxia itself results in the release of bone marrow-derived PACs into circulation.(91) In addition to this direct effect, hypoxia induces the formation and stability of hypoxia inducible factor 1 (HIF-1). The $\alpha$ subunit of HIF-1 is constitutively produced and rapidly degraded in normoxic conditions. In the setting of hypoxia, this degradation is halted and tissue and plasma concentrations are increased, and HIF-1 $\alpha$ subsequently heterodimerizes with the HIF-1 $\beta$ subunit.(92)HIF-1 is closely linked with angiogenesis, and numerous studies have demonstrated its importance in angiogenesis in disease states including cancer, lung injury, and traumatic brain injury.(93)HIF-1, when bound to hypoxia response elements, induces transcription of VEGF, angiopoietin 1 (ANGPT1) and ANGPT2, placental growth factor, platelet derived growth factor B, and in total greater than $2 \%$ of genes encoded by endothelial cells.(94)This results clinically in a compensatory response of the vasculature.(95) This has been shown in the setting of sepsis, wherein HIF-1 $\alpha$ upregulation was essential to endothelial repair in inflammatory lung injury.(96)Insofar as it is related to bone marrow-derived HSCs and CXCL12, the increased concentration of HIF-1 may lead to upregulation of CXCL12 and increased interaction with CXCR4+ PACs. The $\alpha$ subunit of an alternate isoform of HIF - HIF- $2 \alpha$ - has been shown to enable bone marrow derived cells to overcome CXCL-12/CXCR4 retention signals, thus increasing migration from marrow into circulation, as in the migration of plasma cells in multiple myeloma.(97) In addition to upregulation of HIF, hypoxia upregulates erythropoietin, a hypoxia-regulated glycoprotein which has been extensively studied for both its endocrine effects on erythropoiesis and autocrine/paracrine effects in hypoxia. EPO exerts a chemotactic effect on endothelial cells and functions as a proangiogenic factor much like VEGF or FGF, a phenomenon that has been well-described since at least 1990.(98-100) Moreover, EPO interacts with human mesenchymal 
stem cells to augment angiogenesis, as well as activation of MMP-2.(101)In addition to erythropoiesis, Heeschen and colleagues demonstrated that EPO increased the number of circulating endothelial progenitor cells and hematopoietic stem cells capable of participation in angiogenesis. Santhanam, et al. demonstrated that this process is critically dependent on endothelial nitric oxide synthase (eNOS).(102,103) Endothelial progenitor cells in the presence of EPO show increased survival and efficacy in the setting of pulmonary vascular repair, and ultimately demonstrated improved pulmonary vessel angiogenesis.(104) Furthermore, EPO administration following dermal injury resulted in increased microvessel density at the site of injury.(105) EPO is a potent stimulator of erythroid and hematopoietic progenitors from the bone marrow niche, including cells identified as proangiogenic hematopoietic progenitor cells, and has been shown to be elevated following traumatic injury. Overall, administration of EPO has demonstrated improvement in survival following traumatic injury.(106) Conferring survival benefit, particularly at the vessel and microvessel level, is a phenomenon that is also seen in murine models of LPS-induced acute kidney injury, and speaks to the multi-receptor effects of this molecule.(107)

\section{Conclusion}

Rather than considering angiogenesis as occurring within a small, tightly regulated portion of existing endothelium, research has demonstrated that a small number of circulating and bone marrow-derived cells of hematopoietic lineage facilitate and augment angiogenesis. These cells respond to similar signaling cascades, home to areas of need, and play a crucial role in both signaling and new vessel development. The role that PACs play in the physiologic response to system dysfunction - as in the setting of traumatic injury - is an active area of research. 
Augmenting the activity of these cells has the potential to improve vascularization of healing wounds, transiently ischemic tissues, and injured solid organs. Our goal is to identify pharmacologic or mechanistic means of improving host response to injury and blood vessel formation at areas of greatest need. Much in the way pro-hematopoietic cytokine administration (i.e. EPO) has improved survival in trauma patients, we hope to utilize an understanding of the factors in PAC mobilization to identify alternative methods to improve trauma patient survival.

\section{Future Directions}

As our understanding of the imperative role of endothelial progenitor cells and pro-angiogenic hematopoietic stem cells increases, applications including vascularizing mechanistically constructed tissues allow a peek into possible roles for further evaluation of vascular structures.(108) Identification of PACs allows new technologies to emerge which dramatically enhance how we understand wound healing and oxygen/nutrient delivery. We may then begin to develop targeted therapies for patients in which angiogenesis is key to post-traumatic healing and overall survival.

\section{Acknowledgements}

This work was supported by K08DK113226 from the National Institutes of Health, the Koret

Foundation, The George H. Clowe's Memorial Research Career Development Award, and the Department of Surgery at the Indiana University School of Medicine 


\section{References}

1. Case J, Mead LE, Bessler WK, Prater D, White HA, Saadatzadeh MR, Bhavsar JR, Yoder MC, Haneline LS,Ingram DA: Human CD34+AC133+VEGFR-2+ cells are not endothelial progenitor cells but distinct, primitive hematopoietic progenitors. Exp Hematol 35(7):1109-18, 2007.

2. Peichev M, Naiyer AJ, Pereira D, Zhu Z, Lane WJ, Williams M, Oz MC, Hicklin DJ, Witte L, Moore MA, et al.: Expression of VEGFR-2 and AC133 by circulating human CD34(+) cells identifies a population of functional endothelial precursors. Blood 95(3):952-8, 2000.

3. Kumar M, Bhoi S, Subramanian A, Kamal VK, Mohanty S, Rao DN, Galwankar S: Evaluation of circulating haematopoietic progenitor cells in patients with Trauma Haemorrhagic shock and its correlation with outcomes. International journal of critical illness and injury science 6(2):5660, 2016.

4. Gao X, Xu C, Asada N,Frenette PS: The hematopoietic stem cell niche: from embryo to adult. Development (Cambridge, England) 145(2):dev139691, 2018.

5. Schoenwolf GC, Bleyl SB, Brauer PR,Francis-West PH: Larsen's human embryology. Philadelphia, PA: Churchill Livingstone, 2015, pp. xvi, 554 pages.

6. Sharifpanah F, Behr S, Wartenberg M,Sauer H: Mechanical strain stimulates vasculogenesis and expression of angiogenesis guidance molecules of embryonic stem cells through elevation of intracellular calcium, reactive oxygen species and nitric oxide generation. Biochim Biophys Acta 1863(12):3096-3105, 2016.

7. Risau W,Flamme I: Vasculogenesis. Annu Rev Cell Dev Biol 11:73-91, 1995.

8. Gheorghescu A,Thompson J: Delayed vasculogenesis and impaired angiogenesis due to altered Ang-2 and VE-cadherin levels in the chick embryo model following exposure to cadmium. Pediatr Surg Int 32(2):175-86, 2016.

9. Dejana E, Tournier-Lasserve E,Weinstein BM: The control of vascular integrity by endothelial cell junctions: molecular basis and pathological implications. Dev Cell 16(2):209-21, 2009.

10. Carmeliet P: Angiogenesis in health and disease. Nature Medicine 9(6):653-660, 2003.

11. Dejana E: Endothelial cell-cell junctions: happy together. Nat Rev Mol Cell Biol 5(4):261-70, 2004.

12. Cattelino A, Liebner S, Gallini R, Zanetti A, Balconi G, Corsi A, Bianco P, Wolburg H, Moore R, Oreda B, et al.: The conditional inactivation of the beta-catenin gene in endothelial 
cells causes a defective vascular pattern and increased vascular fragility. J Cell Biol 162(6):111122, 2003.

13. Dvorak HF, Nagy JA, Feng D, Brown LF,Dvorak AM: Vascular permeability factor/vascular endothelial growth factor and the significance of microvascular hyperpermeability in angiogenesis. Curr Top Microbiol Immunol 237:97-132, 1999.

14. Astrof S,Hynes RO: Fibronectins in vascular morphogenesis. Angiogenesis 12(2):165-75, 2009.

15. Zhou X, Rowe RG, Hiraoka N, George JP, Wirtz D, Mosher DF, Virtanen I, Chernousov MA,Weiss SJ: Fibronectin fibrillogenesis regulates three-dimensional neovessel formation. Genes Dev 22(9):1231-43, 2008.

16. Mongiat M, Andreuzzi E, Tarticchio G,Paulitti A: Extracellular Matrix, a Hard Player in Angiogenesis. Int J Mol Sci 17(11), 2016.

17. Yamada M,Sekiguchi K: Chapter Six - Molecular Basis of Laminin-Integrin Interactions. In J. H. Miner (ed): Vol. 76. Academic Press, 2015, pp. 197-229.

18. Gonzalez AM, Gonzales M, Herron GS, Nagavarapu U, Hopkinson SB, Tsuruta D,Jones JC: Complex interactions between the laminin alpha 4 subunit and integrins regulate endothelial cell behavior in vitro and angiogenesis in vivo. Proc Natl Acad Sci U S A 99(25):16075-80, 2002.

19. Di Russo J, Hannocks MJ, Luik AL, Song J, Zhang X, Yousif L, Aspite G, Hallmann R,Sorokin L: Vascular laminins in physiology and pathology. Matrix Biol 57-58:140-148, 2017.

20. Hellström M, Phng L-K, Hofmann JJ, Wallgard E, Coultas L, Lindblom P, Alva J, Nilsson A-K, Karlsson L, Gaiano N, et al.: Dll4 signalling through Notch1 regulates formation of tip cells during angiogenesis. Nature 445(7129):776-780, 2007.

21. Siekmann AF,Lawson ND: Notch signalling limits angiogenic cell behaviour in developing zebrafish arteries. Nature 445(7129):781-784, 2007.

22. Seano G, Chiaverina G, Gagliardi PA, di Blasio L, Puliafito A, Bouvard C, Sessa R, Tarone G, Sorokin L, Helley D, et al.: Endothelial podosome rosettes regulate vascular branching in tumour angiogenesis. Nat Cell Biol 16(10):931-41, 1-8, 2014.

23. Spuul P, Daubon T, Pitter B, Alonso F, Fremaux I, Kramer I, Montanez E,Génot E: VEGFA/Notch-Induced Podosomes Proteolyse Basement Membrane Collagen-IV during Retinal Sprouting Angiogenesis. Cell Reports 17(2):484-500, 2016. 
24. Kick K, Nekolla K, Rehberg M, Vollmar AM,Zahler S: New View on Endothelial Cell Migration: Switching Modes of Migration Based on Matrix Composition. Arterioscler Thromb Vasc Biol 36(12):2346-2357, 2016.

25. Kikkawa Y, Sugawara Y, Harashima N, Fujii S, Ikari K, Kumai J, Katagiri F, Hozumi $\mathrm{K}$,Nomizu M: Identification of laminin alpha5 short arm peptides active for endothelial cell attachment and tube formation. J Pept Sci 23(7-8):666-673, 2017.

26. Reichman-Fried M,Raz E: Blood, blebs and lumen expansion. Nature Cell Biology 18:366, 2016.

27. Gebala V, Collins R, Geudens I, Phng LK,Gerhardt H: Blood flow drives lumen formation by inverse membrane blebbing during angiogenesis in vivo. Nat Cell Biol 18(4):443-50, 2016.

28. Herbert SP,Stainier DYR: Molecular control of endothelial cell behaviour during blood vessel morphogenesis. Nature Reviews Molecular Cell Biology 12(9):551-564, 2011.

29. Bentley K, Franco CA, Philippides A, Blanco R, Dierkes M, Gebala V, Stanchi F, Jones M, Aspalter IM, Cagna G, et al.: The role of differential VE-cadherin dynamics in cell rearrangement during angiogenesis. Nature Cell Biology 16:309, 2014.

30. DiPietro LA: Angiogenesis and wound repair: when enough is enough. Journal of Leukocyte Biology 100(5):979-984, 2016.

31. Duong HT, Erzurum SC,Asosingh K: Pro-angiogenic hematopoietic progenitor cells and endothelial colony-forming cells in pathological angiogenesis of bronchial and pulmonary circulation. Angiogenesis 14(4):411-422, 2011.

32. Asahara T,Kawamoto A: Endothelial progenitor cells for postnatal vasculogenesis. American Journal of Physiology-Cell Physiology 287(3):C572-C579, 2004.

33. Khan SS, Solomon MA,McCoy Jr. JP: Detection of circulating endothelial cells and endothelial progenitor cells by flow cytometry. Cytometry Part B: Clinical Cytometry 64B(1):1$8,2005$.

34. Peichev M, Naiyer AJ, Pereira D, Zhu Z, Lane WJ, Williams M, Oz MC, Hicklin DJ, Witte L, Moore MAS, et al.: Expression of VEGFR-2 and AC133 by circulating human CD34\&lt;sup\&gt;+\&lt;/sup\&gt; cells identifies a population of functional endothelial precursors. Blood 95(3):952, 2000.

35. Case J, Mead LE, Bessler WK, Prater D, White HA, Saadatzadeh MR, Bhavsar JR, Yoder MC, Haneline LS,Ingram DA: Human CD34+AC133+VEGFR-2+ cells are not endothelial 
progenitor cells but distinct, primitive hematopoietic progenitors. Experimental Hematology 35(7):1109-1118, 2007.

36. Rafii S,Lyden D: Therapeutic stem and progenitor cell transplantation for organ vascularization and regeneration. Nature medicine 9(6):702-712, 2003.

37. Liekens S, Schols D,Hatse S: CXCL12-CXCR4 Axis in Angiogenesis, Metastasis and Stem Cell Mobilization. Current Pharmaceutical Design 16(35):3903-3920, 2010.

38. Dar A, Kollet O,Lapidot T: Mutual, reciprocal SDF-1/CXCR4 interactions between hematopoietic and bone marrow stromal cells regulate human stem cell migration and development in NOD/SCID chimeric mice. Experimental Hematology 34(8):967-975, 2006.

39. Cashen AF, Nervi B,DiPersio J: AMD3100: CXCR4 antagonist and rapid stem cellmobilizing agent. Future Oncology 3(1):19-27, 2007.

40. Broxmeyer HE, Orschell CM, Clapp DW, Hangoc G, Cooper S, Plett PA, Liles WC, Li X, Graham-Evans B, Campbell TB, et al.: Rapid mobilization of murine and human hematopoietic stem and progenitor cells with AMD3100, a CXCR4 antagonist. The Journal of Experimental Medicine 201(8):1307-1318, 2005.

41. Liles WC, Broxmeyer HE, Rodger E, Wood B, Hübel K, Cooper S, Hangoc G, Bridger GJ, Henson GW, Calandra G, et al.: Mobilization of hematopoietic progenitor cells in healthy volunteers by AMD3100, a CXCR4 antagonist. Blood 102(8):2728, 2003.

42. Larochelle A, Krouse A, Metzger M, Orlic D, Donahue RE, Fricker S, Bridger G, Dunbar CE,Hematti P: AMD3100 mobilizes hematopoietic stem cells with long-term repopulating capacity in nonhuman primates. Blood 107(9):3772-3778, 2006.

43. Bach HH, Saini V, Baker TA, Tripathi A, Gamelli RL,Majetschak M: Initial Assessment of the Role of CXC Chemokine Receptor 4 after Polytrauma. Molecular Medicine 18(7):10561066, 2012.

44. Singh P, Mohammad KS,Pelus LM: CXCR4 expression in the bone marrow microenvironment is required for hematopoietic stem and progenitor cell maintenance and early hematopoietic regeneration after myeloablation. Stem Cells, 2020.

45. Sherman LS, Hannoush E, Sifri ZC, Mohr A,Livingston DH: SDF-1 Is Elevated in Trauma Patients at the Site of Injury. Journal of Surgical Research 158(2):410-411, 2010.

46. Franchini S, Marcianò T, Sorlini C, Campochiaro C, Tresoldi M, Sabbadini MG,Dagna L: Serum CXCL12 levels on hospital admission predict mortality in patients with severe sepsis/septic shock. Am J Emerg Med 33(12):1802-4, 2015. 
47. Hu C, Yong X, Li C, Lü M, Liu D, Chen L, Hu J, Teng M, Zhang D, Fan Y, et al.:

CXCL12/CXCR4 axis promotes mesenchymal stem cell mobilization to burn wounds and contributes to wound repair. Journal of Surgical Research 183(1):427-434, 2013.

48. Lapidot T, Dar A,Kollet O: How do stem cells find their way home? Blood 106(6):1901, 2005.

49. Jin DK, Shido K, Kopp HG, Petit I, Shmelkov SV, Young LM, Hooper AT, Amano H, Avecilla ST, Heissig B, et al.: Cytokine-mediated deployment of SDF-1 induces

revascularization through recruitment of CXCR4+ hemangiocytes. Nat Med 12(5):557-67, 2006.

50. Visse R,Nagase H: Matrix Metalloproteinases and Tissue Inhibitors of Metalloproteinases.

Circulation Research 92(8):827-839, 2003.

51. Kawai K, Xue F, Takahara T, Kudo H, Yata Y, Zhang W,Sugiyama T: Matrix

metalloproteinase-9 contributes to the mobilization of bone marrow cells in the injured liver. Cell Transplant 21(2-3):453-64, 2012.

52. Nagy B, Szélig L, Rendeki S, Loibl C, Rézmán B, Lantos J, Bogár L,Csontos C: Dynamic changes of matrix metalloproteinase 9 and tissue inhibitor of metalloproteinase 1 after burn injury. Journal of critical care 30(1):162-166, 2015.

53. Belizon A, Kirman I, Balik E, Karten M, Jain S,Whelan RL: Major surgical trauma induces proteolysis of insulin-like growth factor binding protein-3 in transgenic mice and is associated with a rapid increase in circulating levels of matrix metalloproteinase-9. Surgical endoscopy 21(4):653-658, 2007.

54. Gonzalez RJ, Lin S-A, Bednar B, Connolly B, LaFranco-Scheuch L, Mesfin GM, Philip T, Patel S, Johnson T, Sistare FD, et al.: Vascular Imaging of Matrix Metalloproteinase Activity as an Informative Preclinical Biomarker of Drug-induced Vascular Injury. Toxicologic pathology 45(5):633-648, 2017.

55. Hoffmann U, Hoffmann U, Bertsch T, Hoffmann U, Bertsch T, Dvortsak E, Liebetrau C, Lang S, Liebe V, Huhle G, et al.: Matrix-metalloproteinases and their inhibitors are elevated in severe sepsis: Prognostic value of TIMP-1 in severe sepsis. Scandinavian Journal of Infectious Diseases 38(10):867-872, 2006.

56. Mühl D, Nagy B, Woth G, Falusi B, Bogár L, Weber G,Lantos J: Dynamic changes of matrix metalloproteinases and their tissue inhibitors in severe sepsis. J Crit Care 26(6):550-5, 2011.

57. Yazdan-Ashoori P, Liaw P, Toltl L, Webb B, Kilmer G, Carter DE,Fraser DD: Elevated plasma matrix metalloproteinases and their tissue inhibitors in patients with severe sepsis. J Crit Care 26(6):556-65, 2011. 
58. Vandooren J, Swinnen W, Ugarte-Berzal E, Boon L, Dorst D, Martens E,Opdenakker G: Endotoxemia shifts neutrophils with TIMP-free gelatinase B/MMP-9 from bone marrow to the periphery and induces systematic upregulation of TIMP-1. Haematologica 102(10):1671-1682, 2017.

59. Theodore LN, Hagedorn EJ, Cortes M, Natsuhara K, Liu SY, Perlin JR, Yang S, Daily ML, Zon LI,North TE: Distinct Roles for Matrix Metalloproteinases 2 and 9 in Embryonic Hematopoietic Stem Cell Emergence, Migration, and Niche Colonization. Stem cell reports 8(5):1226-1241, 2017.

60. Taraboletti G, D'Ascenzo S, Borsotti P, Giavazzi R, Pavan A,Dolo V: Shedding of the matrix metalloproteinases MMP-2, MMP-9, and MT1-MMP as membrane vesicle-associated components by endothelial cells. Am J Pathol 160(2):673-80, 2002.

61. Heissig B, Hattori K, Dias S, Friedrich M, Ferris B, Hackett NR, Crystal RG, Besmer P, Lyden D, Moore MA, et al.: Recruitment of stem and progenitor cells from the bone marrow niche requires MMP-9 mediated release of kit-ligand. Cell 109(5):625-37, 2002.

62. Monteiro R, Pinheiro P, Joseph N, Peterkin T, Koth J, Repapi E, Bonkhofer F, Kirmizitas A,Patient R: Transforming Growth Factor $\beta$ Drives Hemogenic Endothelium Programming and the Transition to Hematopoietic Stem Cells. Developmental Cell 38(4):358-370, 2016.

63. Holderfield MT,Hughes CC: Crosstalk between yascular endothelial growth factor, notch, and transforming growth factor-beta in vascular morphogenesis. Circ Res 102(6):637-52, 2008.

64. Jarad M, Kuczynski EA, Morrison J, Viloria-Petit AM,Coomber BL: Release of endothelial cell associated VEGFR2 during TGF- $\beta$ modulated angiogenesis in vitro. BMC Cell Biology 18(1):10, 2017.

65. Yahata T, Ibrahim AA, Muguruma Y, Eren M, Shaffer AM, Watanabe N, Kaneko S, Nakabayashi T, Dan T, Hirayama N, et al.: TGF- $\beta$-induced intracellular PAI-1 is responsible for retaining hematopoietic stem cells in the niche. Blood 130(21):2283-2294, 2017.

66. Menger MD,Vollmar B: Surgical trauma: hyperinflammation versus immunosuppression? Langenbecks Arch Surg 389(6):475-84, 2004.

67. Rottiers P, Saltel F, Daubon T, Chaigne-Delalande B, Tridon V, Billottet C, Reuzeau E,Génot E: TGF $\beta$-induced endothelial podosomes mediate basement membrane collagen degradation in arterial vessels. Journal of Cell Science 122(23):4311, 2009.

68. Varon C, Tatin F, Moreau V, Van Obberghen-Schilling E, Fernandez-Sauze S, Reuzeau E, Kramer I,Génot E: Transforming Growth Factor $\beta$ Induces Rosettes of Podosomes in Primary Aortic Endothelial Cells. Molecular and Cellular Biology 26(9):3582, 2006. 
69. Wu W, Duan Y, Ma G, Zhou G, Park-Windhol C, D'Amore PA,Lei H: AAV-CRISPR/Cas9Mediated Depletion of VEGFR2 Blocks Angiogenesis In Vitro. Investigative ophthalmology \& visual science 58(14):6082-6090, 2017.

70. Bomsztyk K, Mar D, An D, Sharifian R, Mikula M, Gharib SA, Altemeier WA, Liles WC,Denisenko O: Experimental acute lung injury induces multi-organ epigenetic modifications in key angiogenic genes implicated in sepsis-associated endothelial dysfunction. Crit Care 19(1):225, 2015.

71. Guo J, Yan W, Yang Y, Wang Z,Tian F: Monitoring of vascular endothelial growth factor and its soluble receptor levels in early trauma. J Trauma Acute Care Surg 82(4):766-770, 2017.

72. Melincovici CS, Bosca AB, Susman S, Marginean M, Mihu C, Istrate M, Moldovan IM, Roman AL,Mihu CM: Vascular endothelial growth factor (VEGF) - key factor in normal and pathological angiogenesis. Rom J Morphol Embryol 59(2):455-467, 2018.

73. Wara AK, Foo S, Croce K, Sun X, Icli B, Tesmenitsky Y, Esen F, Lee J-S, Subramaniam M, Spelsberg TC, et al.: TGF- $\beta 1$ signaling and Krüppel-like factor 10 regulate bone marrow-derived proangiogenic cell differentiation, function, and neovascularization. Blood 118(24):6450-6460, 2011.

74. Wara AK, Manica A, Marchini JF, Sun X, Icli B, Tesmenitsky Y, Croce K,Feinberg MW: Bone marrow-derived Kruppel-like factor 10 controls reendothelialization in response to arterial injury. Arteriosclerosis, thrombosis, and vascular biology 33(7):1552-1560, 2013.

75. Boon RA, Urbich C, Fischer A, Fontijn RD, Seeger FH, Koyanagi M, Horrevoets AJ,Dimmeler S: Kruppel-like factor 2 improves neovascularization capacity of aged proangiogenic cells. Eur Heart J 32(3):371-7, 2011.

76. Wang Y, Yang C, Gu Q, Sims M, Gu W, Pfeffer LM, Yue J: KLF4 Promotes Angiogenesis by Activating VEGF Signaling in Human Retinal Microvascular Endothelial Cells. PloS one 10(6):e0130341-e0130341, 2015.

77. Helbing T, Volkmar F, Goebel U, Heinke J, Diehl P, Pahl HL, Bode C, Patterson C,Moser M: Kruppel-like factor 15 regulates BMPER in endothelial cells. Cardiovasc Res 85(3):551-9, 2010.

78. Nagai R, Suzuki T, Aizawa K, Shindo T,Manabe I: Significance of the transcription factor KLF5 in cardiovascular remodeling. J Thromb Haemost 3(8):1569-76, 2005.

79. Molina PE: Neurobiology of the stress response: contribution of the sympathetic nervous system to the neuroimmune axis in traumatic injury. Shock (Augusta, Ga.) 24(1):3-10, 2005. 
80. Kalinkovich A, Spiegel A, Shivtiel S, Kollet O, Jordaney N, Piacibello W,Lapidot T: Bloodforming stem cells are nervous: Direct and indirect regulation of immature human CD34+ cells by the nervous system. Brain, Behavior, and Immunity 23(8):1059-1065, 2009.

81. Katayama Y, Battista M, Kao W-M, Hidalgo A, Peired AJ, Thomas SA,Frenette PS: Signals from the Sympathetic Nervous System Regulate Hematopoietic Stem Cell Egress from Bone Marrow. Cell 124(2):407-421, 2006.

82. Xiang M, Yuan Y, Fan L, Li Y, Li A, Yin L, Scott MJ, Xiao G, Billiar TR, Wilson MA, et al.: Role of macrophages in mobilization of hematopoietic progenitor cells from bone marrow after hemorrhagic shock. Shock (Augusta, Ga.) 37(5):518-523, 2012.

83. Méndez-Ferrer S, Lucas D, Battista M,Frenette PS: Haematopoietic stem cell release is regulated by circadian oscillations. Nature 452:442, 2008.

84. Spiegel A, Shivtiel S, Kalinkovich A, Ludin A, Netzer N, Goichberg P, Azaria Y, Resnick I, Hardan I, Ben-Hur H, et al.: Catecholaminergic neurotransmitters regulate migration and repopulation of immature human CD34+ cells through Wnt signaling. Nature Immunology 8(10):1123-1131, 2007.

85. Levi-Montalcini R: The Nerve Growth Factor 35 Years Later. Science 237(4819):1154-1162, 1987.

86. Nico B, Mangieri D, Benagiano V, Crivellato E, Ribatti D: Nerve growth factor as an angiogenic factor. Microvascular Research 75(2):135-141, 2008.

87. Cantarella G, Lempereur L, Presta M, Ribatti D, Lombardo G, Lazarovici P, ZappalÀ G, Pafumi C,Bernardini R: Nerve growth factor-endothelial cell interaction leads to angiogenesis in vitro and in vivo. The FASEB Journal 16(10):1307-1309, 2002.

88. Gibran NS, Tamura R, Tsou R,Isik FF: Human dermal microvascular endothelial cells produce nerve growth factor: implications for wound repair. Shock (Augusta, Ga.) 19(2):127130, 2003.

89. Rahbek UL, Dissing S, Thomassen C, Hansen AJ,Tritsaris K: Nerve growth factor activates aorta endothelial cells causing PI3K/Akt- and ERK-dependent migration. Pflügers Archiv 450(5):355-361, 2005.

90. Lazarovici P, Marcinkiewicz C,Lelkes PI: Cross Talk between the Cardiovascular and Nervous Systems:Neurotrophic Effects of Vascular Endothelial Growth Factor (VEGF) and Angiogenic Effects of Nerve Growth Factor (NGF)-Implications in Drug Development. Current Pharmaceutical Design 12(21):2609-2622, 2006. 
91. Antoniou ES, Sund S, Homsi EN, Challenger LF,Rameshwar P: A theoretical simulation of hematopoietic stem cells during oxygen fluctuations: prediction of bone marrow responses during hemorrhagic shock. Shock (Augusta, Ga.) 22(5):415-422, 2004.

92. Wang GL, Jiang BH, Rue EA,Semenza GL: Hypoxia-inducible factor 1 is a basic-helix-loophelix-PAS heterodimer regulated by cellular $\mathrm{O} 2$ tension. Proceedings of the National Academy of Sciences 92(12):5510, 1995.

93. Bagnall J, Leedale J, Taylor SE, Spiller DG, White MRH, Sharkey KJ, Bearon RN,Sée V: Tight control of hypoxia-inducible factor- $\alpha$ transient dynamics is essential for cell survival in hypoxia. The Journal of biological chemistry 289(9):5549-5564, 2014.

94. Manalo DJ, Rowan A, Lavoie T, Natarajan L, Kelly BD, Shui QY, Garcia JG,Semenza GL: Transcriptional regulation of vascular endothelial cell responses to hypoxia by HIF-1. Blood 105(2):659-669, 2005.

95. Zhang Y, Ming J, Li T, Yang G, Xu J, Chen W,Liu L: regulatory effects of hypoxiainducible factor 1alpha on vascular reactivity and its mechanisms following hemorrhagic shock in rats. Shock (Augusta, Ga.) 30(5):557-562, 2008.

96. Huang X, Zhang X, Zhao DX, Yin J, Hu G, Evans CE,Zhao Y-Y: Endothelial HypoxiaInducible Factor- $1 \alpha$ Is Required for Vascular Repair and Resolution of Inflammatory Lung Injury through Forkhead Box Protein M1. The American journal of pathology 189(8):1664-1679, 2019.

97. Vandyke K, Zeissig MN, Hewett DR, Martin SK, Mrozik KM, Cheong CM, Diamond P, To LB, Gronthos S, Peet DJ, et al.: HIF-2alpha Promotes Dissemination of Plasma Cells in Multiple Myeloma by Regulating CXCL12/CXCR4 and CCR1. Cancer Res 77(20):5452-5463, 2017.

98. Anagnostou A, Lee ES, Kessimian N, Levinson R,Steiner M: Erythropoietin has a mitogenic and positive chemotactic effect on endothelial cells. Proceedings of the National Academy of Sciences 87(15):5978-5982, 1990.

99. Anagnostou A, Liu Z, Steiner M, Chin K, Lee ES, Kessimian N,Noguchi CT: Erythropoietin receptor mRNA expression in human endothelial cells. Proceedings of the National Academy of Sciences 91(9):3974-3978, 1994.

100. Ribatti D, Presta M, Vacca A, Ria R, Giuliani R, Dell'Era P, Nico B, Roncali L,Dammacco F: Human erythropoietin induces a pro-angiogenic phenotype in cultured endothelial cells and stimulates neovascularization in vivo. Blood 93(8):2627-2636, 1999.

101. Zwezdaryk KJ, Coffelt SB, Figueroa YG, Liu J, Phinney DG, LaMarca HL, Florez L, Morris CB, Hoyle GW,Scandurro AB: Erythropoietin, a hypoxia-regulated factor, elicits a pro- 
angiogenic program in human mesenchymal stem cells. Experimental Hematology 35(4):640$652,2007$.

102. Santhanam AVR, d'Uscio LV, Peterson TE,Katusic ZS: Activation of endothelial nitric oxide synthase is critical for erythropoietin-induced mobilization of progenitor cells. Peptides 29(8):1451-1455, 2008.

103. Heeschen C, Aicher A, Lehmann R, Fichtlscherer S, Vasa M, Urbich C, Mildner-Rihm C, Martin H, Zeiher AM,Dimmeler S: Erythropoietin is a potent physiologic stimulus for endothelial progenitor cell mobilization. Blood 102(4):1340-1346, 2003.

104. Hu R, Cheng Y, Jing H,Wu H: Erythropoietin promotes the protective properties of transplanted endothelial progenitor cells against acute lung injury via PI3K/Akt pathway. Shock (Augusta, Ga.) 42(4):327-336, 2014.

105. Buemi M, Galeano M, Sturiale A, Ientile R, Crisafulli C, Parisi A, Catania M, Calapai G, Impalà $\mathrm{P}$, Aloisi $\mathrm{C}$, et al.: Recombinant human erythropoietin stimulates angiogenesis and healing of ischemic skin wounds. Shock (Augusta, Ga.) 22(2):169-173, 2004.

106. Napolitano LM, Fabian TC, Kelly KM, Bailey JA, Block EF, Langholff W, Enny C,Corwin HL: Improved Survival of Critically Ill Trauma Patients Treated With Recombinant Human Erythropoietin. Journal of Trauma and Acute Care Surgery 65(2):285-299, 2008.

107. Stoyanoff TR, Rodríguez JP, Todaro JS, Colavita JPM, Torres AM,Aguirre MV: Erythropoietin attenuates LPS-induced microvascular damage in a murine model of septic acute kidney injury. Biomed Pharmacother 107:1046-1055, 2018.

108. Peters EB: Endothelial Progenitor Cells for the Vascularization of Engineered Tissues. Tissue Eng Part B Rev 24(1):1-24, 2018.

109. Chen T-J, Wu W-Q, Ying G-R, Fu Q-Y,Xiong K: Serum CXCL12 concentration in patients with severe traumatic brain injury are associated with mortality. Clinica Chimica Acta 454:6-9, 2016.

110. Jelkmann W: Regulation of erythropoietin production. The Journal of physiology $589(\mathrm{Pt}$ 6):1251-1258, 2011.

111. Bible LE, Pasupuleti LV, Gore AV, Sifri ZC, Kannan KB,Mohr AM: Chronic restraint stress after injury and shock is associated with persistent anemia despite prolonged elevation in erythropoietin levels. J Trauma Acute Care Surg 79(1):91-6; discussion 96-7, 2015. 
112. Alamo IG, Kannan KB, Loftus TJ, Ramos H, Efron PA,Mohr AM: Severe trauma and chronic stress activates extramedullary erythropoiesis. J Trauma Acute Care Surg 83(1):144-150, 2017.

113. Fagerberg L, Hallström BM, Oksvold P, Kampf C, Djureinovic D, Odeberg J, Habuka M, Tahmasebpoor S, Danielsson A, Edlund K, et al.: Analysis of the human tissue-specific expression by genome-wide integration of transcriptomics and antibody-based proteomics. Molecular \& cellular proteomics : MCP 13(2):397-406, 2014.

114. Meert KL, Ofenstein JP, Genyea C, Sarnaik AP,Kaplan J: Elevated Transforming Growth Factor-beta Concentration Correlates with Posttrauma Immunosuppression. Journal of Trauma and Acute Care Surgery 40(6):901-906, 1996.

115. Pepper MS, Vassalli JD, Orci L,Montesano R: Biphasic effect of transforming growth factor-beta 1 on in vitro angiogenesis. Exp Cell Res 204(2):356-63, 1993.

116. Niyaz M, Gürpınar ÖA, Oktar GL, Günaydın S, Onur MA, Özsin KK,Yener A: Effects of VEGF and MSCs on vascular regeneration in a trauma model in rats. Wound Repair and Regeneration 23(2):262-267, 2015. 


\section{Figure Legends}

Figure 1. Representative flowchart depicting the numerous cellular processes that ultimately result in the release of PACs from bone marrow and the eventual sprouting of neovasculature at the site of injury.

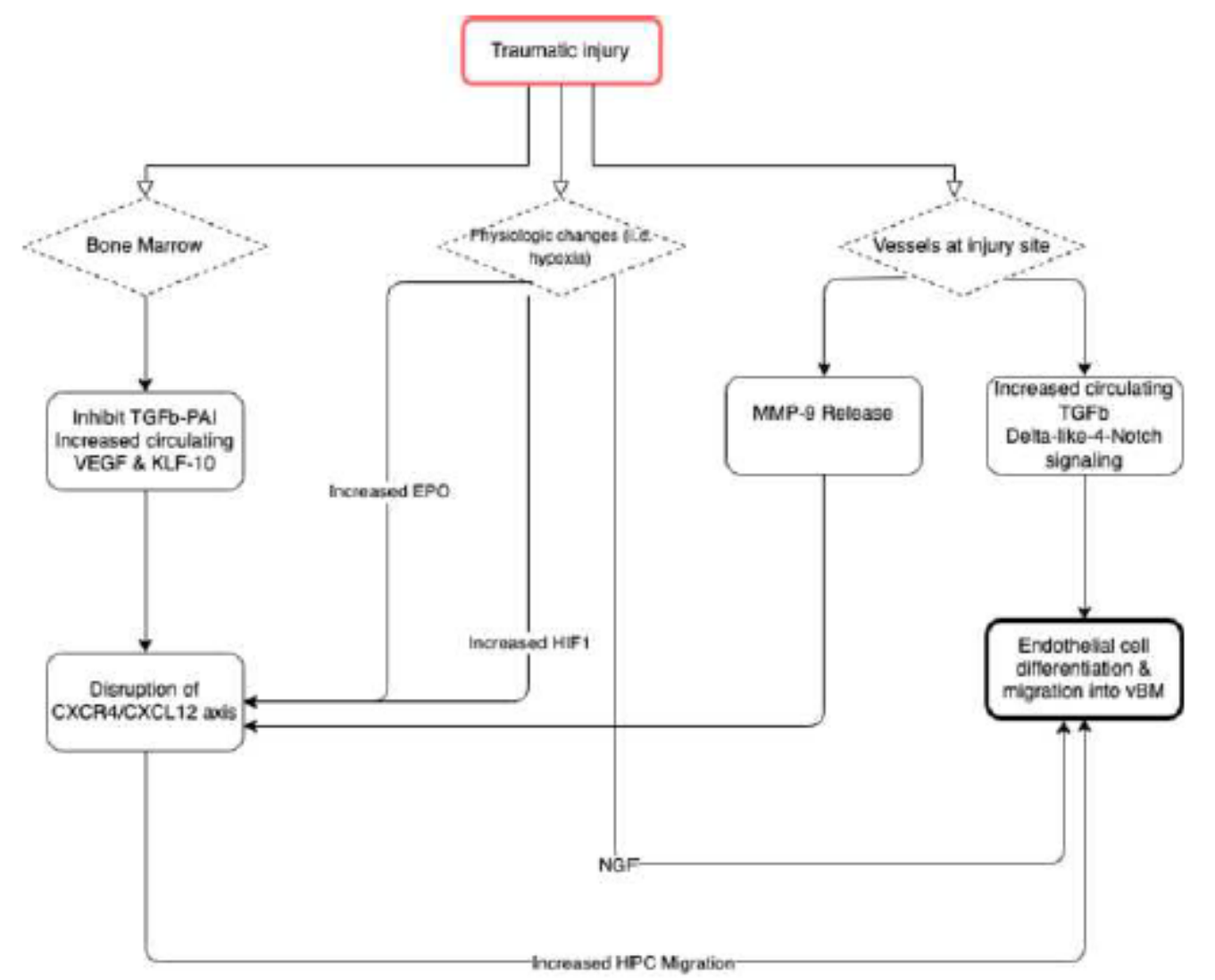


Figure 2. Schematic representation of post-traumatic angiogenesis. A) site of injury; B) Native vasculature at injury site. Circulating platelets contribute to angiogenesis via the release of CXCL12, while adjacent cells at the level of injury release MMP-9, TGF $\beta$, and VEGF to aid in vascular development and recruit additional cells; C) At the level of neovascularization, the budding vessel forms a podosome rosette, led into the vascular basement membrane via endothelial "tip" cells, with "stalk" cells providing progressive support; D) At the level of the endothelial cell, occludins, Jam-1, and VE-Cadherin support the intercellular barrier, adjacent to a vascular basement membrane (vBM) composed of pericam, nidogen, and laminin, supported by a Type IV collagen scaffold; E) Erythropoietin is released from the kidney in response to the heterodimerization of HIF-2.

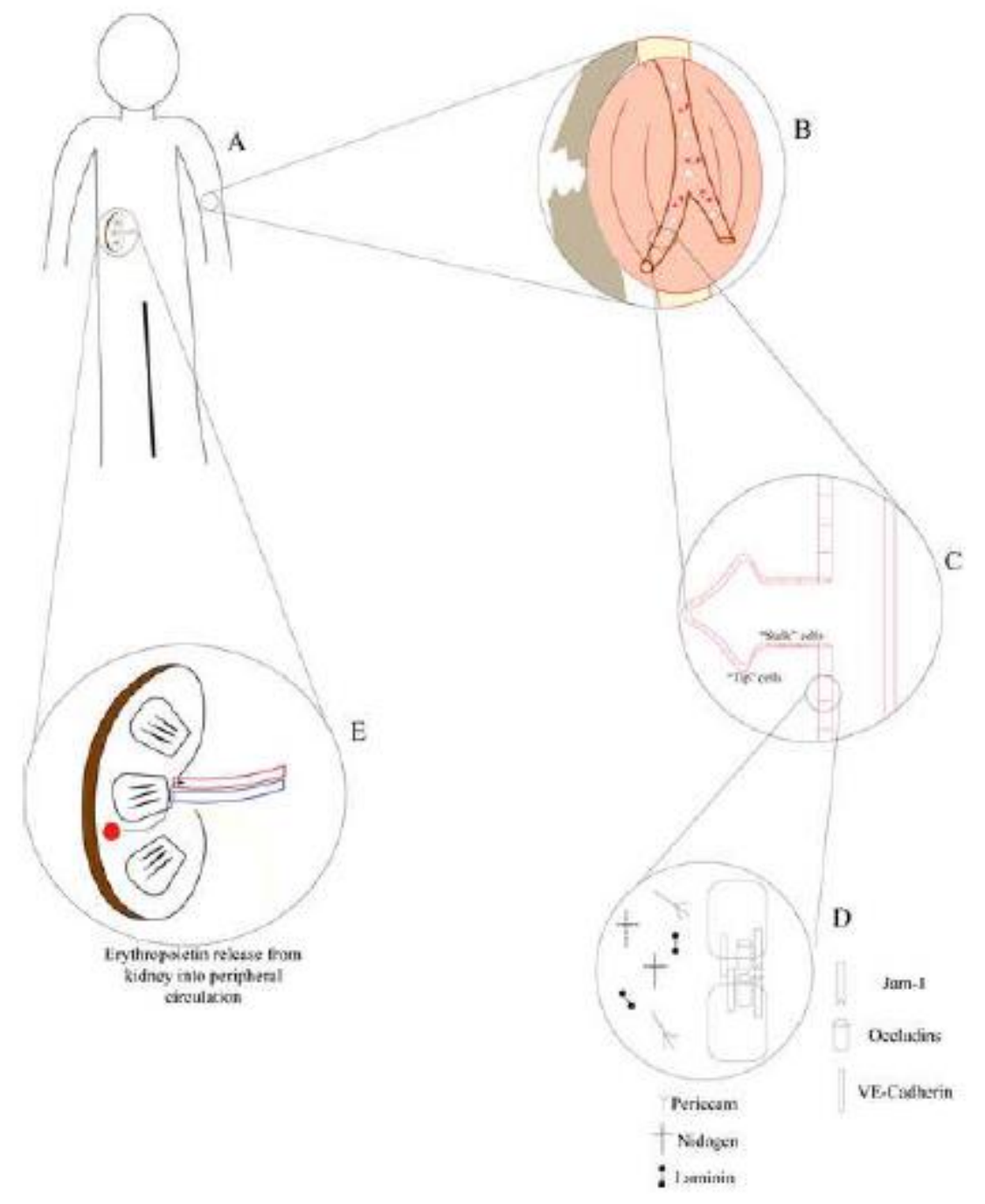


Table 1. Review of key signaling molecules in angiogenesis and mobilization of proangiogenic HSCs.

\begin{tabular}{|c|c|c|c|c|}
\hline Name & $\begin{array}{l}\text { Function in } \\
\text { Angiogenesis }\end{array}$ & $\begin{array}{l}\text { Site of } \\
\text { Production/Rele } \\
\text { ase }\end{array}$ & $\begin{array}{l}\text { Observed Response to } \\
\text { Injury }\end{array}$ & $\begin{array}{l}\text { Experimental } \\
\text { Results }\end{array}$ \\
\hline $\begin{array}{l}\text { Matrix } \\
\text { metalloprotein } \\
\text { ase family }\end{array}$ & $\begin{array}{l}\text { Degradation of } \\
\text { ECM in } \\
\text { advance of } \\
\text { angiogenic } \\
\text { sprouting. } \\
\text { Disruption of } \\
\text { ECM of bone } \\
\text { marrow HSC } \\
\text { niche. }\end{array}$ & Endothelium & Elevated(52-54) & $\begin{array}{l}\text { Inhibition } \\
\text { causes } \\
\text { decreased } \\
\text { vascularity in } \\
\text { zebrafish (59) }\end{array}$ \\
\hline $\begin{array}{l}\text { C-X-C } \\
\text { chemokine } \\
\text { motif ligand } 12 \\
\text { (CXCL12) }\end{array}$ & $\begin{array}{l}\text { Maintenance of } \\
\text { cells in } \\
\text { CXCR4+ niche. } \\
\text { Disruption } \\
\text { leads to } \\
\text { migration of } \\
\text { HSCs from } \\
\text { distant niche. }\end{array}$ & $\begin{array}{l}\text { Constitutively } \\
\text { expressed on } \\
\text { bone marrow } \\
\text { stromal cells }\end{array}$ & $\begin{array}{l}\text { Elevated, } \\
\text { particularly when } \\
\text { CXCL12-CXCR4 } \\
\text { axis impaired (43, } 45 \text {, } \\
\text { 109) }\end{array}$ & $\begin{array}{l}\text { AMD3100 } \\
\text { administration } \\
\text { results in rapid } \\
\text { mobilization of } \\
\text { PACs to } \\
\text { periphery in } \\
\text { mice and } \\
\text { humans (40-42) }\end{array}$ \\
\hline $\begin{array}{l}\text { Hypoxia- } \\
\text { inducible } \\
\text { factor (HIF) }\end{array}$ & $\begin{array}{l}\text { Degradation } \\
\text { inhibited in } \\
\text { response to } \\
\text { hypoxia; } \\
\text { upregulation of } \\
\text { key cytokine } \\
\text { transcription }\end{array}$ & Endothelium & $\begin{array}{l}\text { Elevated with } \\
\text { ischemia }(93,96)\end{array}$ & $\begin{array}{l}\text { Key } \\
\text { transcription } \\
\text { induction, aids } \\
\text { bone marrow } \\
\text { derived cells in } \\
\text { overcoming } \\
\text { CXCL12- } \\
\text { CXCR4 bond } \\
(94,97)\end{array}$ \\
\hline $\begin{array}{l}\text { Erythropoietin } \\
\text { (EPO) }\end{array}$ & $\begin{array}{l}\text { Erythropoiesis, } \\
\text { chemotaxis of } \\
\text { proangiogenic } \\
\text { factors, } \\
\text { maintenance } \\
\text { and promotion } \\
\text { of EPCs }\end{array}$ & $\begin{array}{l}\text { Kidney, in } \\
\text { response to } \\
\text { hypoxia }(110)\end{array}$ & Elevated $(111,112)$ & $\begin{array}{l}\text { Increased } \\
\text { circulating } \\
\text { endothelial } \\
\text { progenitors and } \\
\text { PACs via } \\
\text { eNOS- } \\
\text { dependent } \\
\text { pathway, } \\
\text { autocrine/paracr } \\
\text { ine effects on } \\
\text { angiogenesis } \\
(98,102,103)\end{array}$ \\
\hline $\begin{array}{l}\text { Transforming } \\
\text { growth factor }\end{array}$ & $\begin{array}{l}\text { Low level: } \\
\text { promotion of }\end{array}$ & $\begin{array}{l}\text { Broad } \\
\text { expression, }\end{array}$ & Elevated $(66,114)$ & $\begin{array}{l}\text { Lower doses } \\
\text { promote new }\end{array}$ \\
\hline
\end{tabular}




\begin{tabular}{|c|c|c|c|c|}
\hline (TGF) & $\begin{array}{l}\text { neovascularizati } \\
\text { on } \\
\text { Maintenance of } \\
\text { HSC niche }\end{array}$ & $\begin{array}{l}\text { including } \\
\text { inflammatory } \\
\text { cells and } \\
\text { endothelium(11 } \\
\text { 3) }\end{array}$ & & $\begin{array}{l}\text { vessel formation } \\
\text { (115), maintain } \\
\text { quiescent HSCs } \\
(65)\end{array}$ \\
\hline $\begin{array}{l}\text { Vascular } \\
\text { endothelial } \\
\text { growth factor } \\
\text { (VEGF) }\end{array}$ & $\begin{array}{l}\text { Endothelial } \\
\text { homeostasis } \\
\text { and } \\
\text { maintenance of } \\
\text { vascular } \\
\text { permeability } \\
\text { Mobilization of } \\
\text { proangiogenic } \\
\text { HSCs }\end{array}$ & $\begin{array}{l}\text { Broad } \\
\text { expression, } \\
\text { including } \\
\text { endothelium(11 } \\
\text { 3) }\end{array}$ & $\operatorname{Elevated}(71,72)$ & $\begin{array}{l}\text { MMP-9- } \\
\text { dependent PAC } \\
\text { release, act via } \\
\text { progenitor cells } \\
\text { to induce wound } \\
\text { healing (116) }\end{array}$ \\
\hline $\begin{array}{l}\text { Krüppel-like } \\
\text { factor (KLF) }\end{array}$ & $\begin{array}{l}\text { Mobilization of } \\
\text { pro-angiogenic } \\
\text { precursors } \\
\text { Activation of } \\
\text { VEGF } \\
\text { signaling } \\
\text { cascade }\end{array}$ & $\begin{array}{l}\text { Ubiquitous in } \\
\text { bone marrow, } \\
\text { broadly } \\
\text { expressed } \\
\text { throughout } \\
\text { body(113) }\end{array}$ & & $\begin{array}{l}\text { KLF-10: induce } \\
\text { mobilization of } \\
\text { PACs from } \\
\text { marrow (73); } \\
\text { KLF-4: activate } \\
\text { VEGF signaling } \\
\text { (76) }\end{array}$ \\
\hline $\begin{array}{l}\text { Sympathetic } \\
\text { nervous } \\
\text { system/Nerve } \\
\text { growth factor }\end{array}$ & $\begin{array}{l}\text { HSC } \\
\text { mobilization } \\
\text { from bone } \\
\text { marrow }\end{array}$ & $\begin{array}{l}\text { Throughout the } \\
\text { body consistent } \\
\text { with } \\
\text { sympathetic } \\
\text { nervous system }\end{array}$ & $\begin{array}{l}\text { Hyperactive/elevated } \\
(79,88)\end{array}$ & $\begin{array}{l}\text { PACs express } \\
\text { dopamine/ } \beta \text { - } \\
\text { adrenergic } \\
\text { receptors (80), } \\
\text { Circadian } \\
\text { norepinephrine } \\
\text { release controls } \\
\text { CXCL12 } \\
\text { expression (83) }\end{array}$ \\
\hline
\end{tabular}

